\title{
Magnetite dissolution in deep sediments and its hydrologic implication: A detailed study of sediments from site 808 , leg 131
}

\author{
Ran Lu and Subir K. Banerjee \\ Institute for Rock Magnetism and Department of Geology and Geophysics, University of Minnesota, Minneapolis
}

\begin{abstract}
Our previous study of deep sea sediments from site 808, leg 131 of the Ocean Drilling Program has demonstrated that the two anomalously low-intensity zones of natural remanent magnetization (NRM), 675 to 925 and 1080 to 1243 m below seafloor, were caused by unusually low magnetite content in the sediment sections and that this was not related to the variations in sediment sources, calcite dilution, or magnetite destruction occurring in the top sediment layer during early diagenesis. For an explanation, we now suggest that these low NRM intensity zones were produced by catagenesis at great depth by organic matter decomposition in sediments, which in turn causes magnetite dissolution and hence a lower magnetite content. $\mathbf{A}$ similar process also applies to manganese ions; as a consequence, iron and manganese concentration, grain size and content of magnetite, and NRM intensity all decrease, whereas sulfur content increases in these sediments. Our interpretation is also supported by other studies of organic geochemistry and sedimentology of these same sediments. We suggest, therefore, that detailed rock magnetic and geochemical tests should be carried out before geomagnetic field variations are studied using ocean sediments from such great depth. Additionally, we suspect that catagenesis may have been retarded and magnetic degradation was prevented near a décollement due to cold water percolation.
\end{abstract}

\section{Introduction}

Studies of geomagnetic secular variation and paleointensity are important for understanding the nature of geodynamo behavior and testing the axial dipole hypothesis over geological timescales [McElhinny and Merrill, 1975]. Unfortunately, such magnetic data are available only for about the past $10 \mathrm{kyr}$ from continental studies of archaeomagnetism, lava flows, and lake sediments. Thick ocean sediments are potentially a better alternative for such study due to their continuous magnetic record over much longer time intervals. For example, Tric et al. [1992] studied four cores from the Mediterranean and showed that relative paleointensity had fluctuated over the past $80 \mathrm{kyr}$ with a periodicity of $20 \mathrm{kyr}$. However, the process of magnetic remanence acquisition in sediments is strongly influenced by many factors, including sediment particle size, water and clay mineral contents, electrical conductivity, sediment compaction, etc. [ $L u$ et al., 1990; Kodama and Sun, 1990; Verosub, 1977; King and Channell, 1991]. In addition to these physical processes, chemical alteration may also play an important role. The effects of such nonmagnetic parameters must be sought before we can claim that the observed relative paleointensity represents true geomagnetic field fluctuations.

It has been shown, for example, that natural remanent magnetization (NRM) intensities are greatly diminished in the topmost sediment layer in many lakes and oceans by bacterial activity on organic matter. Within this layer, intense bacterial

Copyright 1994 by the American Geophysical Union.

Paper number 93JB03204. 0148-0227/94/93JB-03204\$05.00 activity breaks organic matter into methane and $\mathrm{CO}_{2}$, resulting in the reduction and dissolution of iron. As a result, magnetic content decreases and NRM intensities in sediments follow suit [Leslie et al., 1990a, b; Karlin, 1990; Canfield and Berner, 1987]. Prior studies in this area have focused on sediments less than $10 \mathrm{~m}$ deep, because bacterial activity becomes much less intense below this depth. To obtain paleomagnetic information extending farther into the past beyond the Quaternary, we need to study sediments from greater depths. This is possible in continental margins where thick sediments and high accumulation rates (about $1 \mathrm{~m} / 1000$ years) allow detailed studies of magnetic secular variation before and during the Quaternary period [Kent and Opdyke, 1977]. However, as sediments are buried, organic matter in deep sediments will undergo further decomposition due to the increase in temperature (catagenesis), as was pointed out by Hunt [1979]. As a result, carbon atoms lose electrons, and light hydrocarbons and $\mathrm{CO}_{2}$ are produced. It is not now known whether such decomposition of organic matter at depth affects the magnetic carriers, thus changing the magnetic signal in sediments, just as shallow depth decomposition does.

To investigate this issue, we have studied in great detail the sediments from Nankai Trench, site 808 of leg 131, Ocean Drilling Program. There are two magnetic advantages in studying these particular sediments: (1) The sediments are about $1300 \mathrm{~m}$ thick, one of the thickest sediment sections ever obtained by deep sea drilling. From the observed temperature gradient, it is most likely that the sediments at depth have reached the minimum temperature for organic decomposition by catagenesis (about $60^{\circ} \mathrm{C}$, [Hunt 1979]), allowing us to make a preliminary study of the effects of organic decomposition on magnetic properties in deep sediments. (2) The presence of a décollement in this hole at $955 \mathrm{~m}$ below 
seafloor (mbsf) depth also provides us with an opportunity to examine the possible influence of the associated fluid flow on magnetic minerals. It has been extensively documented elsewhere that a large volume of fluid from sediments and oceanic plates is released along such highly fractured décollement during the subduction process [Bray and Karig, 1985; Peacock, 1987; Cloos, 1984; Moore, 1989].

We have previously studied the paleomagnetic properties of the sediments of site 808 and found two zones of extremely low NRM intensity in deep sediments (675 to 925 and 1080 to 1243 mbsf), as shown in Figure 1. Within these zones, NRM intensity falls by about 2 orders of magnitude, making magnetic data difficult to measure and hence much less reliable [Lu et al., 1993]. In our previous study, we evaluated several possibilities for the cause of these low-intensity zones. From the lithologic column (see Figure 2) we can see that the major boundary is at depth 618 mbsf, below which most of the sediments (units IVa and IVb) are uniform hemipelagic and pelagic Shikoku basin muds. There is a $61-\mathrm{m}$-thick unit (III) above, constituting a basin-to-trench transition, while units I and II represent coarse-grained turbiditic trench-fill sediments which have suffered much structural disturbance.

The structurally disturbed units I, II, and III display a relatively high median NRM intensity of $\sim 80 \mathrm{~mA} / \mathrm{m}$ but with some very sharp fluctuations due to local faulting and turbidity current effects. The first major transition (high NRM to consistently low NRM) occurs well within the homogeneous unit IVa at $675 \mathrm{mbsf}$ while the unit III/IVa boundary is at 618 mbsf. Similarly, Figure 1 shows that the other (lower) major transitions $(925,1080$, and $1243 \mathrm{mbsf}$ ) to consistently high or low NRM are not correlated with lithologic boundaries. This is one main reason for claiming that the observed lowintensity zones are not lithologically controlled.

The second reason for concluding that the low NRM observed is not an artifact of lithology is that the carbonate content variation (10\%-40\%) within the critical units, IVa and $\mathrm{IVb}$, is nowhere near as strong as the observed 2 orders of magnitude variation in NRM. Finally, the maximum carbonate content occurs at 978 mbsf [Taira et al., 1991], well within a high-NRM zone, located between the low-intensity zones. If

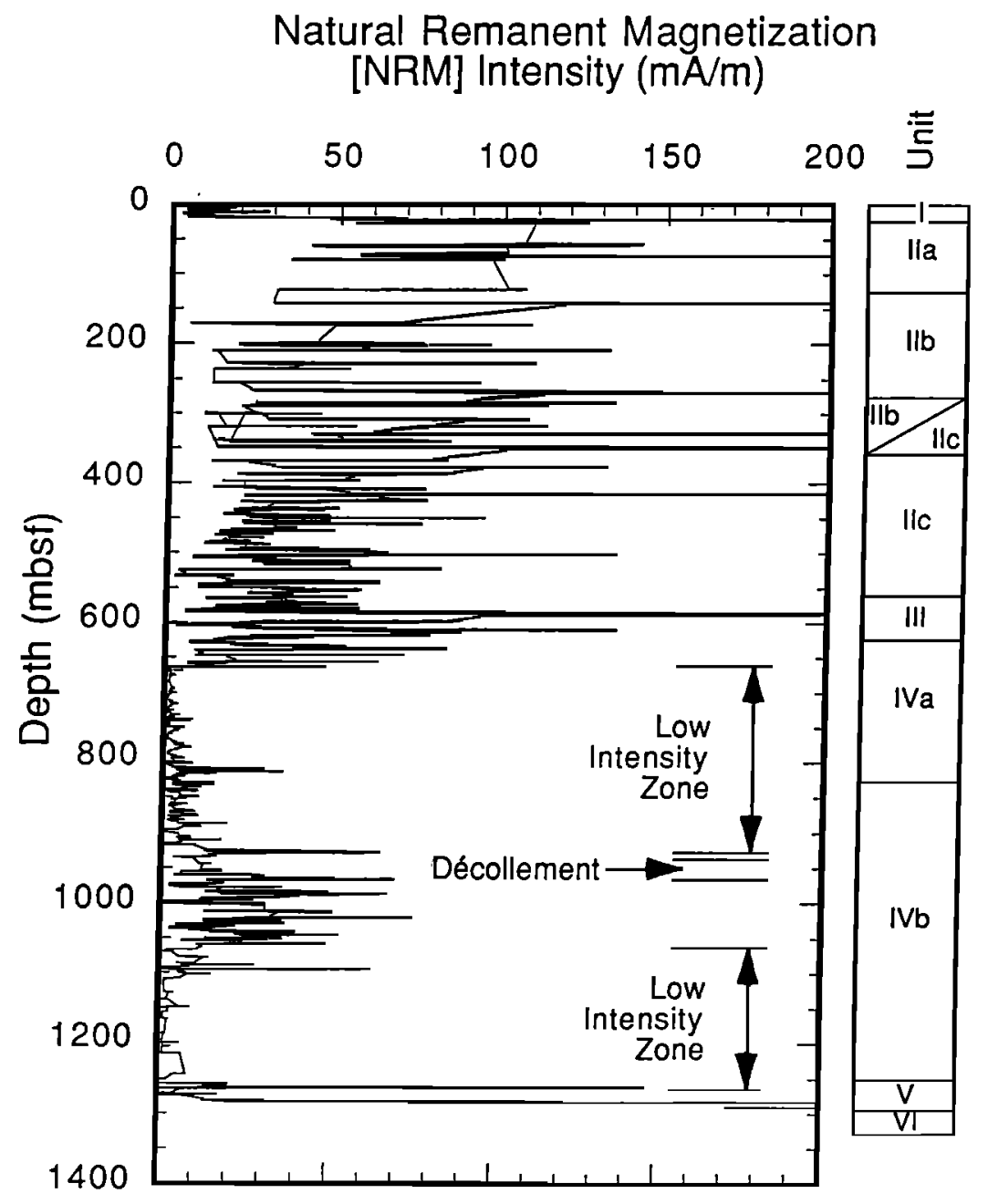

Figure 1. Shipboard magnetic intensity measurements of NRM (five-piont running average with depth). There are two consistently low NRM intensity zones, 675 to 925 and 1080 to 1243 mbsf, within which NRM intensity decreases by 1 to 2 orders of magnitude [after Lu et al., 1993]. Note that the low-intensity zone boundaries do not correlate with lithologic units boundaries. The details of lithology are given in Figure 2. 


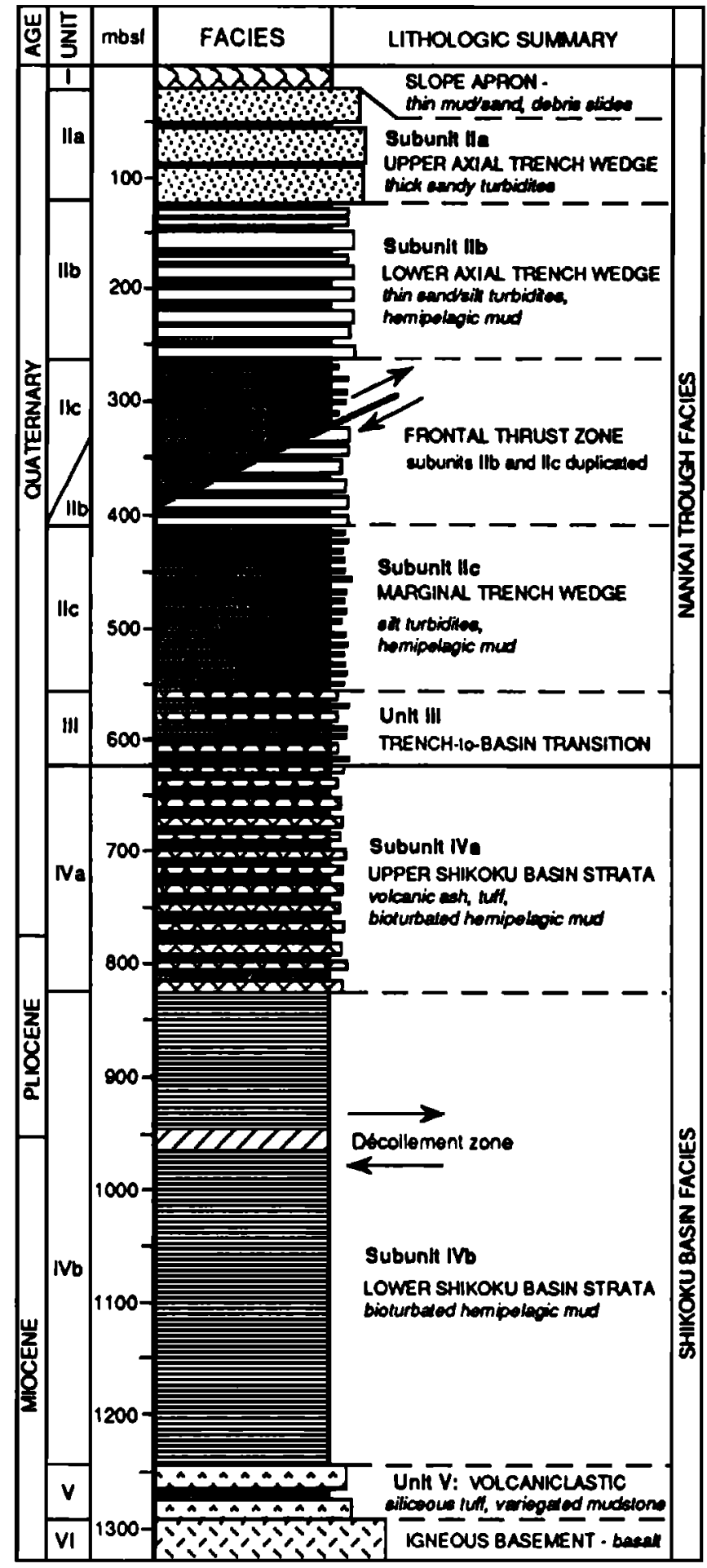

Figure 2. Schematic stratigraphic column for site 808 , based on detailed shipboard core descriptions, sedimentary facies interpretations, and microfossil control (modified from Shipboard Scientific Party [1991]).

dilution by nonmagnetic carbonates was the reason for the existence of the low-intensity zones, the carbonate peak should have coincided with a low in NRM, not a high, as observed here.

Obviously, we need to understand the mechanism responsible for such intensity variations, so that appropriate sediments at depth can be chosen for future magnetic studies.
In addition, the relatively high intensity zone located between the low-intensity zones includes a décollement. A décollement is a structurally disharmonious zone or surface, indicated most commonly in seismic reflection data [Moore, 1989]. It is formed when sediments are accumulated at a trench area. Along a décollement, sediments are separated into an inbricated thrust complex above and almost undeformed sediments below. The décollement at site 808 is a 19 -m-thick zone at $955 \mathrm{mbsf}$ [Taira et al., 1991]. Observations on accretionary prisms have confirmed that a décollement is the main conduit of fluid flow from a subduction zone. Melanges, formed along ancient décollement zones, show extensive vent communities which mark the paleo-hydrothermal flows [Peacock, 1987]. Magnetic study of this interval may provide some useful information about the interactions of magnetic minerals with fluid flow.

\section{Experiments}

Our rock magnetic measurements were aimed at clarifying the magnetic mineralogy and grain size of the sediments. In a previous study [ $L u$ et al., 1993], magnetite was identified as the major magnetic mineral in the sediments of site 808 from the measurements of saturation magnetization, Xray diffraction, and Curie point. We also attempted to estimate the relative magnetic grain size with the $A R M / k_{0}$ ratio (anhysteretic remanent magnetization/low field susceptibility) following King et al. [1982]. With a decrease in grain size, ARM becomes stronger and $k_{0}$ weaker, although both remain proportional to the total magnetic content. Therefore, the $\mathrm{ARM} / \mathrm{k}_{0}$ ratio is controlled by changes in relative magnetic grain size, not concentration. A high ratio of $A R M / k_{0}$ indicates smaller (single-domain (SD) and pseudo-singledomain (PSD) ) grain sizes, while low ratios indicate multi domain grains. However, as discussed in previous papers [King et al., 1982; Lu et al., 1993], $\mathrm{k}_{0}$ is an effective parameter only when no more than one magnetic mineral is dominant. Since $\mathrm{k}_{0}$ was very small in the low-intensity zones, paramagnetic susceptibility $\left(k_{p}\right)$ from iron-bearing clay minerals might have contributed a significant portion to $\mathrm{k}_{0}$, making it necessary to correct observed $k_{0}$ for the $k_{p}$ contribution. Such a correction was made in the current study using additional magnetic hysteresis measurements.

Induced magnetization $J$ versus magnetic field $H$ was measured with a vibrating sample magnetometer. The sample was magnetized in a continuously increasing magnetic field. Measurements of magnetization were taken every $5 \mathrm{mT}$. Samples were all saturated by a field of $300 \mathrm{mT}$, as indicated by closed loops (see Figure 3). After $300 \mathrm{mT}$, the magnetization continued to increase slowly with the increasing external field because of the presence of paramagnetic minerals (ironbearing silicates and carbonates) in the samples. Therefore, paramagnetic susceptibility $\mathrm{k}_{\mathrm{p}}$ was measured from the slope of the curve above $300 \mathrm{mT}$ and was calculated from the equation

$$
M=k_{p} \times H+M_{S}
$$

where $M$ is the total magnetization, $M_{S}$ is the saturation magnetization of the ferrimagnetic fraction (magnetite), and $\mathrm{H}$ is the field intensity. The maximum magnetizing field was $\mathbf{5 0 0}$ $\mathrm{mT}$. The $\mathrm{k}_{\mathrm{p}}$ was determined from the slope of a straight line fitted to 40 data points between 300 and $500 \mathrm{mT}$. After reaching $500 \mathrm{mT}$, the magnetizing field was decreased slowly 


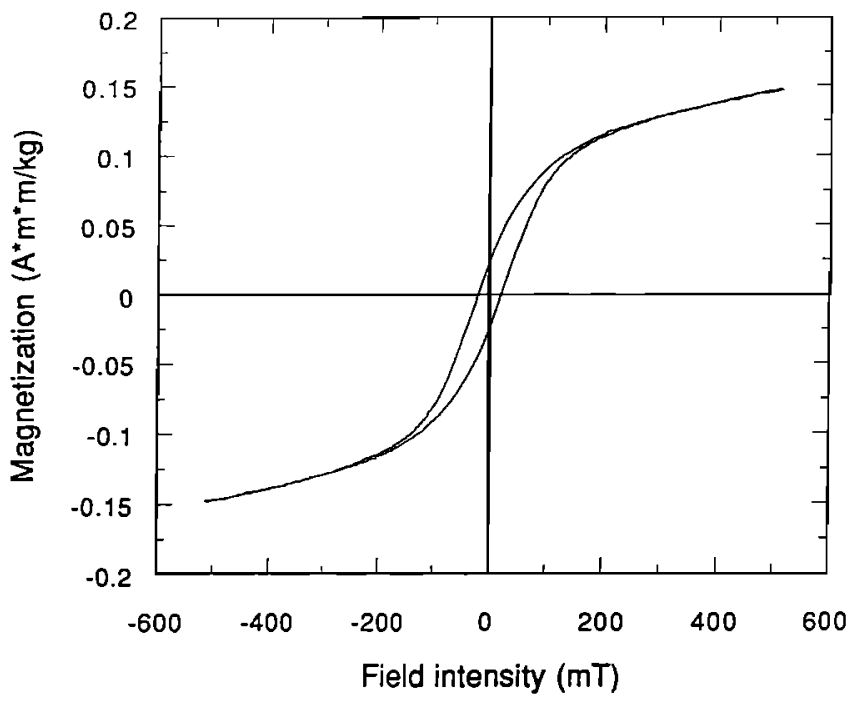

Figure 3. Magnetic hysteresis loop. Loop closes to a line at a field of $300 \mathrm{mT}$, suggesting that the ferrimagnetic component, magnetite, is magnetically saturated by $300 \mathrm{mT}$. The slope from $300 \mathrm{mT}$ to $500 \mathrm{mT}$ is used to obtain paramagnetic susceptibility $\left(\mathrm{K}_{\mathrm{p}}\right)$.

to zero and then increased in the opposite direction to $-500 \mathrm{mT}$ and decreased to zero again, completing a whole hysteresis loop measurement. The total sweep time was $15 \mathrm{~min}$.

A by-product of magnetic hysteresis measurement was saturation remanence $\left(\mathrm{J}_{\mathrm{rs}}\right)$ at $\mathrm{H}=0$, which is the remanence remaining after a saturation field is removed. $\mathrm{J}_{\mathrm{rs}}$ can be used to obtain the ratio $A R M / J_{r s}$ which can also be used to investigate the relative variation in magnetic grain size [Dunlop, 1986], similar to the method based on ARM/ko. ARM is mostly contributed by the finer single-domain and pseudo-single domain grains, roughly $0.03 \mu \mathrm{m}$ to $10 \mu \mathrm{m}$ for magnetite. On the other hand, $\mathrm{J}_{\mathrm{rs}}$ is due to the contribution of all grain sizes, both fine and coarse. Therefore, the ratio of $A R M / J_{r s}$ is proportional to the relative content of fine grains and is not affected by contributions from paramagnetic materials which, by definition, cannot carry remanent magnetization. In other words, higher $A R M / J_{\text {rs }}$ ratios correspond to finer grain sizes and vice versa, as has been shown experimentally [Dankers, 1978; Hartstra, 1982; Özdemir and Banerjee,1982; Maher, 1988].

Analysis of chemical elemental concentrations was conducted on thirty-three sample powders representing the depth interval of about 350 to 1282 mbsf. Twenty-five sample powders were analyzed by using direct current plasma; the remaining eight sample powders were done by induced current plasma with mass spectrometry. Twenty-five elements were examined, and analytical uncertainty was estimated to be less than $1 \%$ based on the calibration against a Geological Society of America standard. Large $(\sim 150 \mathrm{mg})$ aliquots of these thirtythree sample powders were also measured for solid sulfur content with a sulfur Coulometric analyzer. From the measurement of standards, the analytical error for sulfur was estimated to be less than $1 \%$. Eight samples were analyzed twice to check the reproducibility of the measurements. The results were generally consistent with an uncertainty of less than $3 \%$.

\section{Results}

Our first observation is that in the clay-rich sediments, paramagnetic susceptibility $\left(k_{p}\right)$ is high and can be nearly equal to $k_{0}\left(=k_{p}+k_{f}\right)$, the conventionally measured low field susceptibility. The first result is that $A R M / k_{0}$ can no longer provide information relevant to the relative grain size of magnetite. The second result is that even when we correct for the clay contribution to $k_{o}$ by measuring $k_{f}\left(=k_{o}-k_{p}\right), A R M / k_{f}$ data (Figure 4) become unstable in the low-intensity zones where the magnetite content has been drastically reduced. This was confirmed independently by measuring saturation magnetization, which was an order of magnitude smaller, paralleling the NRM variation [Lu et al., 1993]. The wild swings of $A R M / k_{f}$ seen in Figure 4 are, therefore, not physically real but an artifact of subtracting two small numbers from each other.

On the other hand, we find that $A R M / J_{r s}$ is a more appropriate ratio that can be used for grain size determination [Özdemir and Banerjee, 1982; Dunlop, 1986; Maher, 1988] in our case. Unlike $k_{f}, J_{r s}$ can be much more accurately determined than $\mathbf{k}_{\mathbf{f}}$ with a vibrating sample magnetometer, or with a cryogenic magnetometer, even when samples have weak magnetizations. It is also measured directly, rather than determined by subtraction. As mentioned before, a large $\mathrm{ARM} / \mathrm{J}_{\mathrm{rs}}$ indicates relatively small particle sizes, and Figure 5 shows that in the low-intensity zones, the ratio increases from

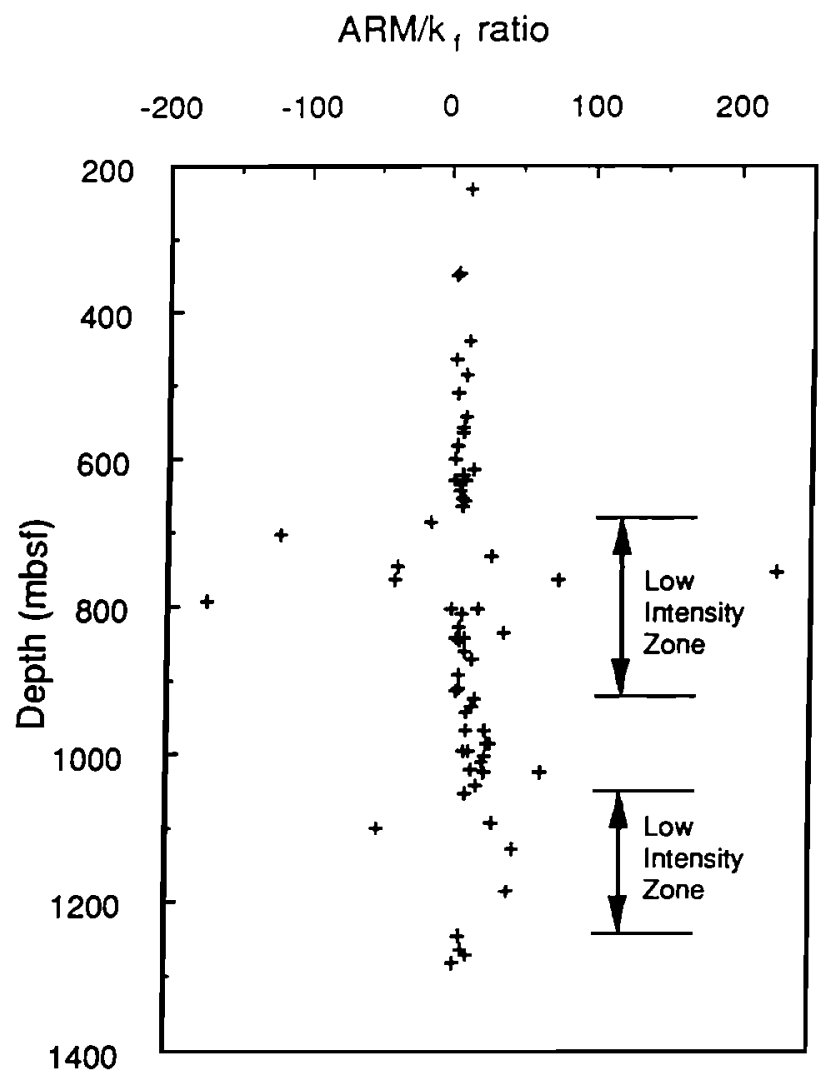

Figure 4. Ratio of anhysteretic remanent magnetization to ferrimagnetic susceptibility (ARM/ $\mathrm{k}_{\mathrm{f}}$ ). In the low-intensity zones, the ratio becomes unstable, showing negative and positive values. This is an artifact due to $k_{p}$ being nearly equal to $k_{o}$ and $k_{f}=k_{o}-k_{p}$. The data are physically unreal and should be rejected in favor of $\mathrm{ARM} / \mathrm{J}_{\mathrm{rs}}$, shown in Figure 5. 


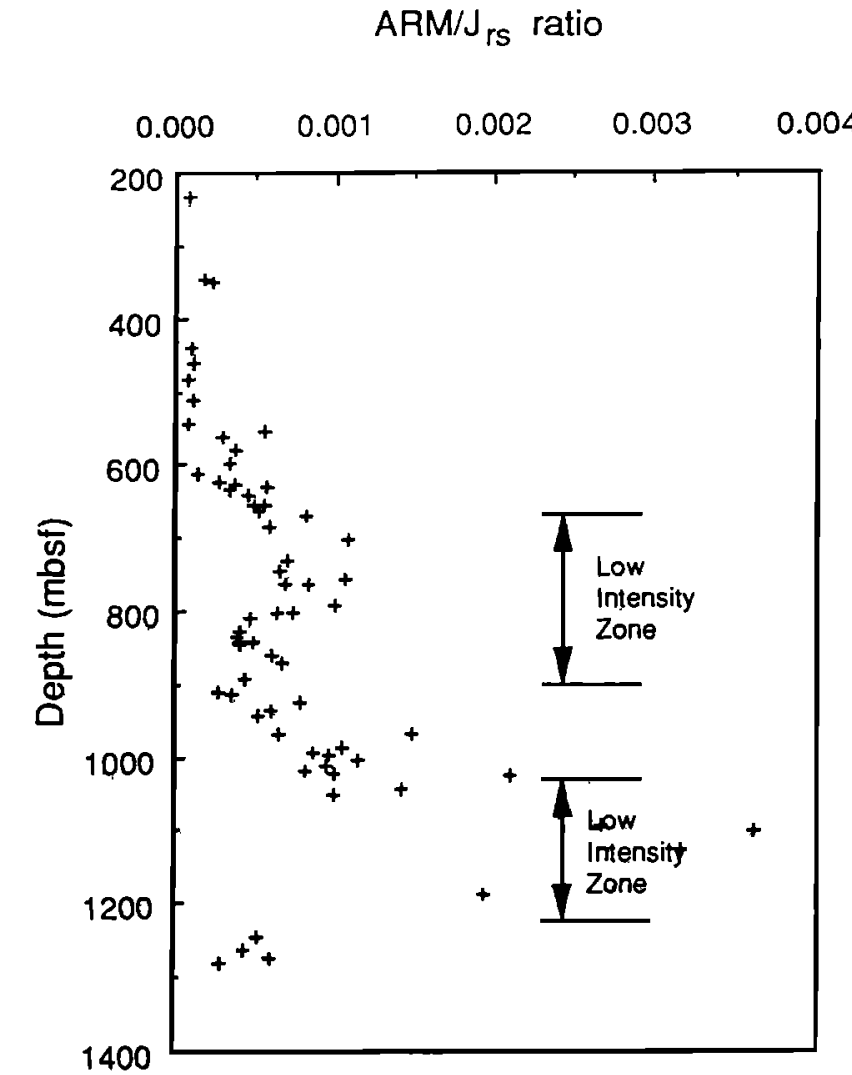

Figure 5. Measurements of anhysteretic remanent magnetization to saturation remanent magnetization $\left(A R M / J_{r s}\right)$. The ratio becomes relatively large in the lowintensity zones, indicating the presence of fine grains of single-domain (SD) and pseudo-single-domain (PSD) states.

$10^{-4}$ to $4 \times 10^{-3}$, indicating smaller grain sizes in these intervals. Thus, although measuring $\mathrm{J}_{\mathrm{IS}}$ is a slower procedure than measuring $\mathrm{k}_{0}$, it provides more accurate data for samples with large paramagnetic concentrations.

Another approach to obtain relative grain size, partial ARM (pARM [Jackson et al. 1988]) was not successful in our previous study [ $L u$ et al., 1993]. It was found that pARM reaches peak intensity in much higher alternating field intervals (AF windows) for high-intensity samples than for the low-intensity ones, suggesting apparently coarser grain sizes in the low-intensity zones. This apparent discrepancy in magnetic grain sizes determined from $\mathrm{PARM}$ and $\mathrm{ARM} / \mathrm{J}_{\mathrm{rs}}$ can now be explained by postulating the presence of ultrafine or superparamagnetic $(<0.03 \mu \mathrm{m})$ particles in low-intensity zones. It is known that for magnetite, magnetic coercivity increases with decreasing grain size, but decreases again if particles are less than $0.03 \mu \mathrm{m}$ [Maher, 1988]. Here PARM actually measures the coercivity distribution in samples [Jackson et al., 1988]. For high-coercivity samples with SD and PSD grains, the intensity of pARM peaks at high AF windows. However, if such samples contain enough superparamagnetic grains, due to magnetostatic interaction the median coercivity will decrease, and the pARM spectrum will move to low AF windows [Özdemir and Banerjee, 1982]. Therefore, we suspect that in addition to paramagnetic clay minerals, superparamagnetic magnetite grains are also present in the low-intensity zones.
From chemical analysis, two elements, sulfur and manganese, are found to have characteristic downhole variations. For the low-intensity zone samples, sulfur content is about twice that of the high-intensity zone samples (Figure 6). Sulfur in ocean sediments can be derived from iron sulfide, evaporites, organic matter, and elemental sulfur; the latter two are usually negligible due to their extremely low contents [Kaplan et al., 1963]. In the sediments from site 808, evaporites were not present but pyrite was abundant [Taira et al., 1991]. It has also been well recognized that pyrite is the major iron sulfide in marine sediments [Goldhaber and Kaplan, 1974; Leslie et al., 1990a, b]. Therefore, it is reasonable to assume that the sulfur in our samples is mainly in the form of pyrite. In contrast to sulfur values, manganese content decreases in the low-intensity zones by about 2 orders of magnitude (Figure 7), similar to NRM intensity variation (Figure 1).

We will now discuss the combined relevance of our magnetic and chemical data in the next section.

\section{Discussion}

The consistently low intensity zones found in this study were difficult to explain initially. They span depth intervals from 675 to 925 and 1080 to $1243 \mathrm{mbsf}$, corresponding to a total elapsed time of about 5 m.y. NRM intenșities decrease greatly in these zones, almost by 1 to 2 orders of magnitude. As shown previously by our saturation magnetization measurements [ $L u$ et al., 1993], the low-intensity zones are produced by a smaller amount of magnetic material in the

\section{Sulfur content (\%)}

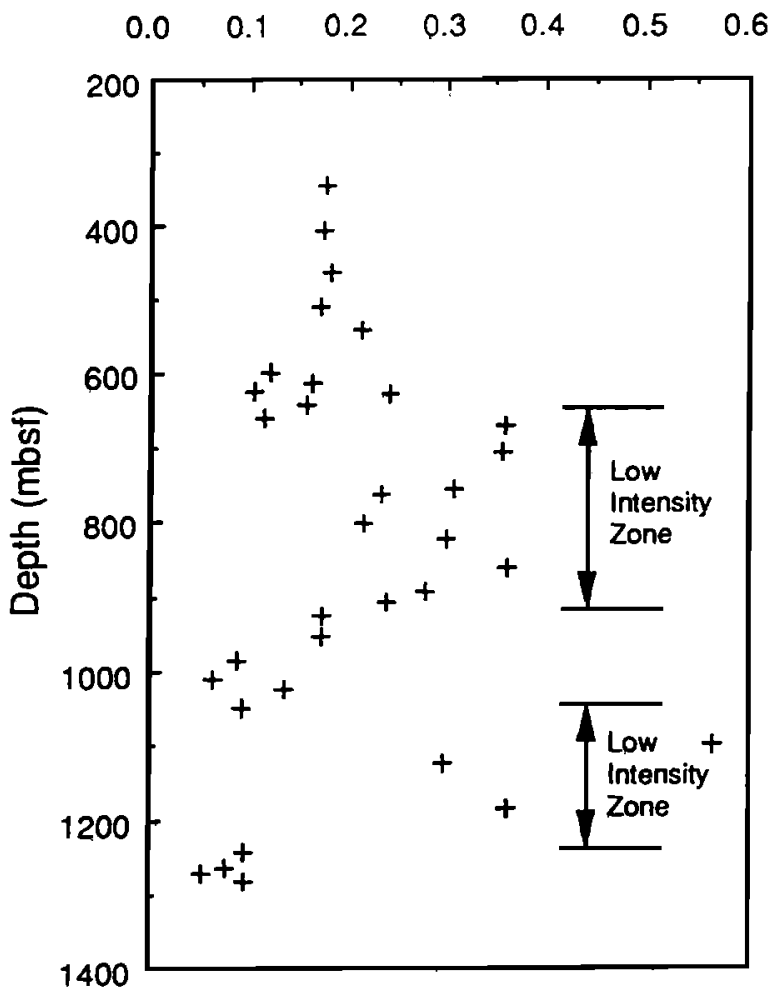

Figure 6. Sulphur content in the solid phase versus depth. High values are found in the low-intensity zones, indicating organic decomposition and sulfide formation. 


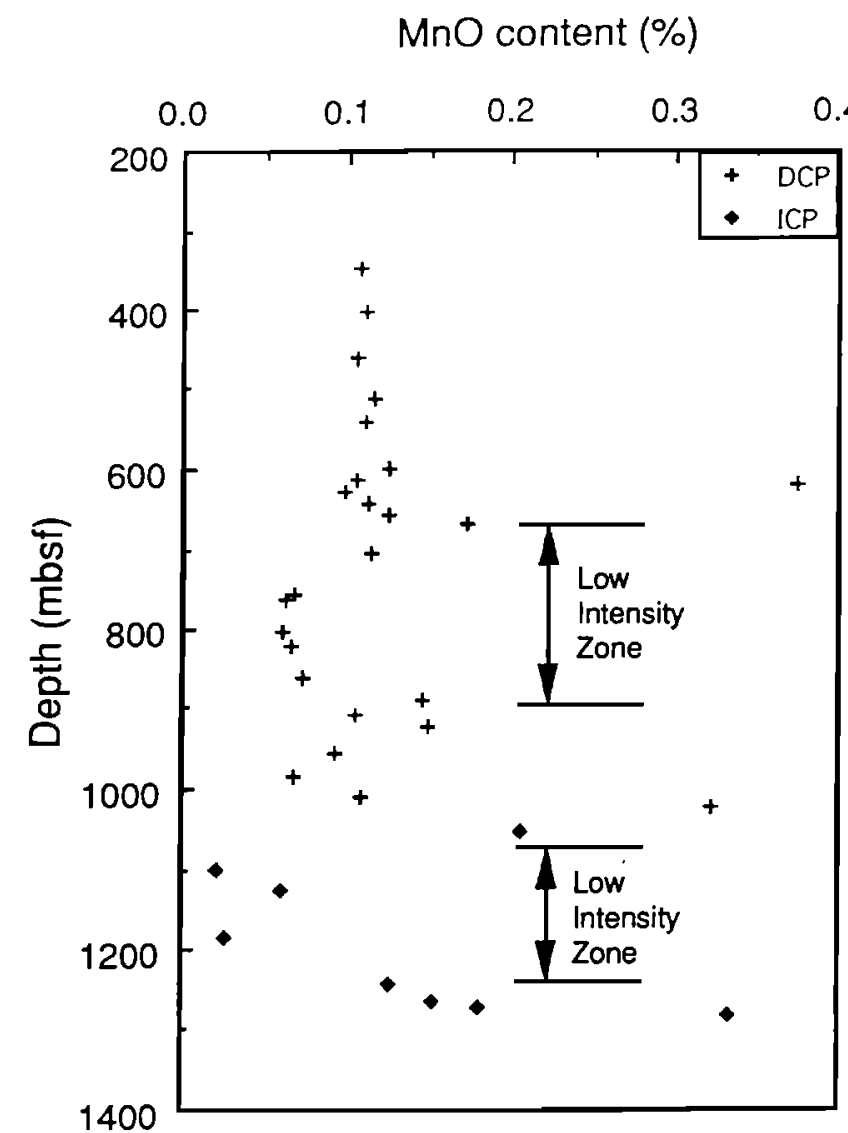

Figure 7. Manganese content versus depth. The plot shows lower content in the low-intensity zones, as is the case for sulfur and is due to reduction of $\mathrm{Mn}^{4+}$.

sediments, not by a weaker paleomagnetic field. However, the zone boundaries were found to be related neither to the variations of sediment sources (Figure 1), nor to the wellknown magnetite dissolution by bacterial activity on organic matter in the top sediment layer. There was no correlation between the low-intensity zones and sediment units, and the first low-intensity zone was located at 675 mbsf, much deeper than what is expected from previous studies of early diagenesis. Relative calcite content variation in the lowintensity zone was found to be limited to horizons much thinner than the low-intensity zones and not sufficient to reduce the NRM intensity by 1 to 2 orders of magnitude. Furthermore, the peak concentration of calcite occurred at a depth of $978 \mathrm{mbsf}$, where the NRM intensity was high and not low, which would be the case if dilution of magnetic content was important. Therefore, we have to turn to the potential diagenetic processes dominant in deep sediments to explain our results.

Previously unaltered organic matter can be altered at depth by catagenesis due to an increase in temperature with depth. Catagenesis temperature ranges from about $60^{\circ} \mathrm{C}$ to about $200^{\circ} \mathrm{C}$, when organic matter decomposes to light-molecularweight hydrocarbons and produces a large amount of $\mathrm{CO}_{2}$ [Hunt, 1979]. Since this occurs in deep sediment sections, light hydrocarbons can be preserved, and $\mathrm{CO}_{2}$ will cause a precipitation of $\mathrm{CaCO}_{3}$ if there is enough $\mathrm{Ca}^{2+}$ available in the pore water. The production of $\mathrm{CO}_{2}$ is an oxidation process, which also results in reduction of $\mathrm{Mn}^{4+}, \mathrm{Fe}^{3+}$, and $\mathrm{SO}_{4}{ }^{2-}$ by electron transfer from organic carbon, causing dissolution of magnetite similar to what happens in the shallow subsurface. At site 808 , a temperature of $39^{\circ} \mathrm{C}$ was recorded at $350 \mathrm{mbsf}$, which was the deepest measurement made at this site. This yields an average temperature gradient of $111^{\circ} \mathrm{C} / \mathrm{km}$ [Taira et al., 1991]. By extrapolation, the temperature at $675 \mathrm{mbsf}$ should be $75^{\circ} \mathrm{C}$, which is high enough to break down organic matter by catagenesis. We suggest that it is this decomposition of organic matter that diminishes the NRM intensity in the sediments at depth. Once catagenesis takes place, changes of magnetic properties and geochemical anomalies will follow.

As $\mathrm{Fe}^{3+}$ in magnetite grains is reduced to $\mathrm{Fe}^{2+}$ by accepting an electron from carbon, magnetite particles are gradually dissolved. This is clearly compatible with the low NRM intensities and $\mathbf{k}_{\mathrm{f}}$ values. Since dissolution takes place on the magnetic particle surfaces [Canfield and Berner, 1987], magnetic grain sizes become smaller. Such diagenesis, when early and at a shallow depth ( $<10 \mathrm{mbs}$ ), does produce a net increase in magnetite grain size because the smallest grains are attacked and dissolved first. In our case, these sediments at depth have already experienced this early diagenesis, therefore mainly coarse grains are available for further dissolution, resulting in a net decrease of grain size, as seen by the magnetic proxies. As shown in Figure 4, ARM/J $\mathrm{J}_{\mathrm{rs}}$ is higher in the low NRM intensity zones, suggesting smaller magnetic grains present in these sections. $\mathrm{Fe}^{2+}$ from the dissolved magnetite grains will precipitate as pyrite by combining with $\mathrm{S}-$ from $\mathrm{SO}_{4}{ }^{2-}$ in pore water through a reduction process initiated by catagenesis. As a result, pyrite content increases in the low NRM intensity zones, as shown by the sulfur anomalıes (Figure 6). Like $\mathrm{Fe}^{3+}$, oxidized $\mathrm{Mn}^{4+}$ will also accept electrons to form reduced $\mathrm{Mn}^{2-}$, which then moves into pore water. However, $\mathrm{Mn}$ sulfide does not form because it is an unstable mineral phase. Therefore, as $\mathrm{Mn}^{4+}$ is reduced, the concentration of solid phase $\mathrm{Mn}$ decreases in the low-intensity zone (Figure 7).

Our suggestion that the low NRM intensity zones were caused by organic decomposition at depth is also supported by organic geochemistry and sedimentological observations. When organic matter decomposes at shallow depths during early diagenesis, methane is produced. But at great depths, during catagenesis, light-molecular-weight hydrocarbons, such as butane and pentane, will be produced as well as $\mathrm{CO}_{2}$ [Hunt, 1979]. If the overburial sediments are relatively impermeable, these gases will be preserved in the sediments. Organic gas measurement has identified high concentrations, about $0.5 \mu \mathrm{L} / \mathrm{kg}$, of butane and pentane but no methane (Figure 8) in the low-intensity zones [Taira et al., 1991], suggesting that organic matter here has reached a relatively high degree of maturity. Similarly, sedimentological observation showed that calcite contents increased in the low-intensity zones (Figure 9). This is probably related to the production of $\mathrm{CO}_{2}$ during organic decomposition. Unlike hydrocarbons, $\mathrm{CO}_{2}$ is easily dissolved in pore water and combines with $\mathrm{Ca}^{2+}$ to precipitate calcite.

A good correlation between sudden decreases at depth in NRM intensities and hydrocarbon gases was also observed, but left unexplained, in two previous Ocean Drilling Project sites. At site $671 \mathrm{~B}$ of leg 110 on the Barbados Ridge, it was found that NRM intensity decreased sharply by 2 orders of magnitude at about 500 mbsf, whereas methane content increased to its maximum at that depth [Mascle and Moore, 1986]. Similarly, 
(a) Butane content $(\mu \mathrm{L} / \mathrm{kg})$

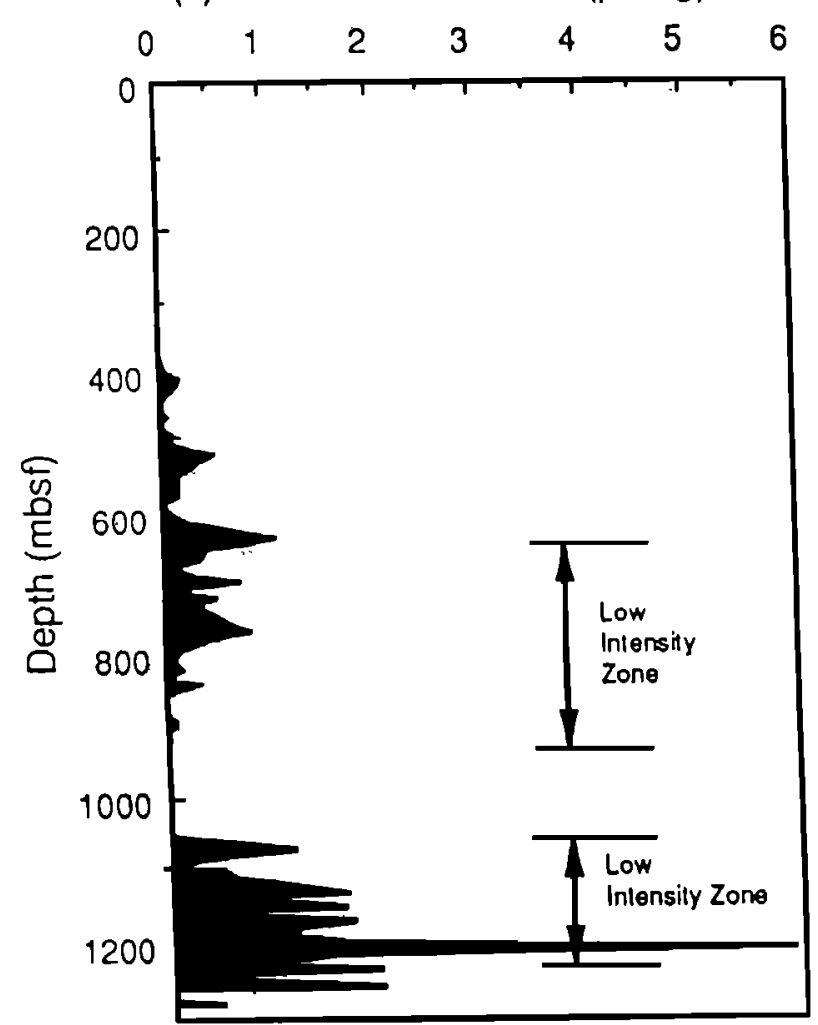

(b) Pentane content $(\mu \mathrm{L} / \mathrm{kg})$

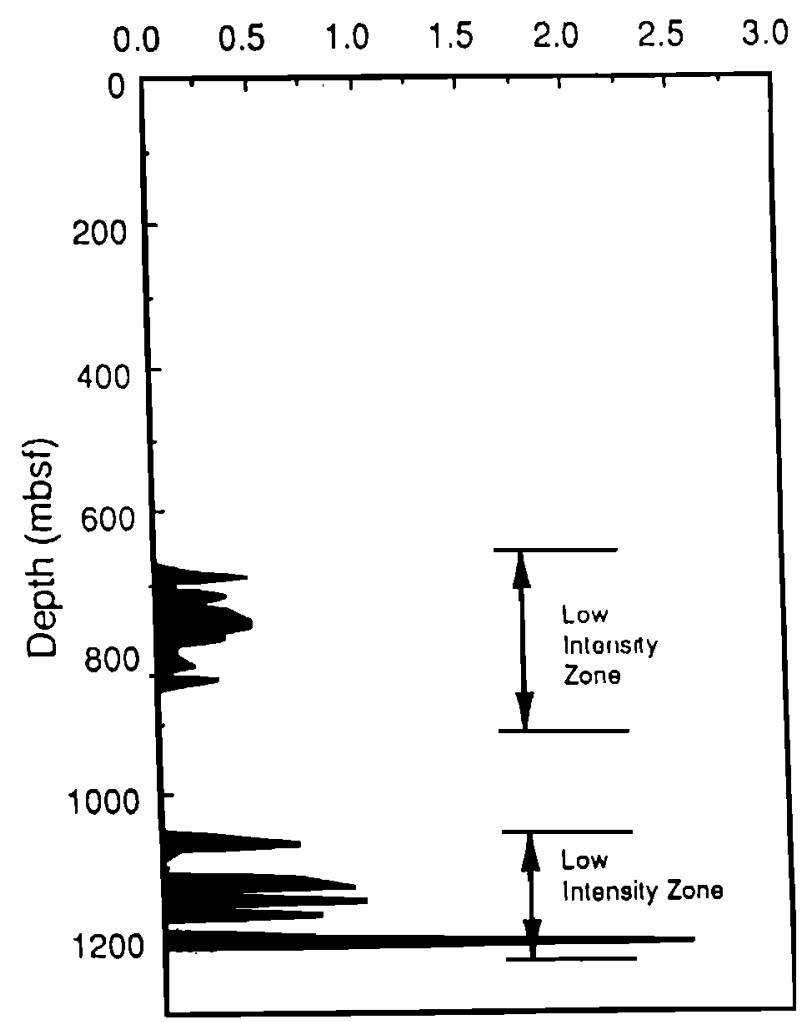

Figure 8. Figure 8. Distributions of (a) butane and (b) pentane versus depth. Relative higher contents exist in the low-intensity zones [after Taira et al., 1991].

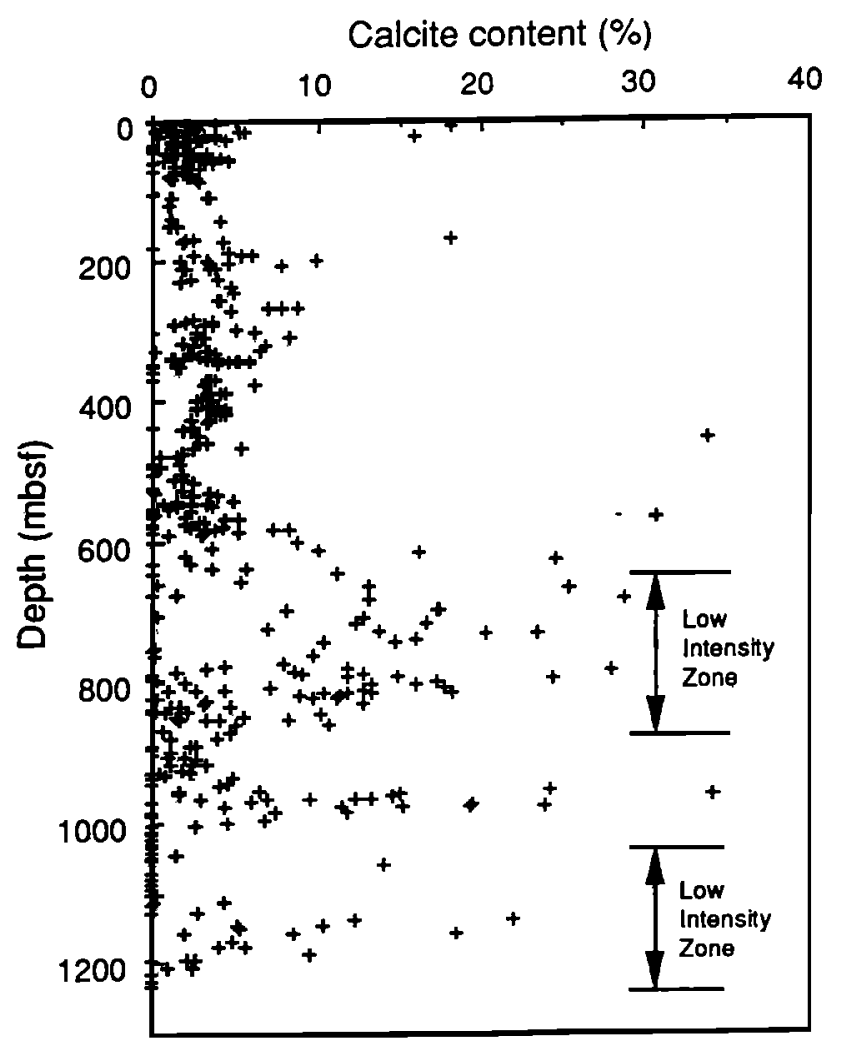

Figure 9. Calcite content versus depth. It also shows relatively high values in the low-intensity zones, similar to hydrocarbon gas distributions in Figure 8 [after Taira et al., 19.91]. at site 767 of leg 124, located in the Celebes and Sulu Sea, there was a low magnetic susceptibility zone, equivalent to a low NRM intensity zone, at about 400 to 600 mbsf. Within this zone, the amount of methane and ethane increased [Rangin and Silver, 1989], indicating the occurrence of organic matter decomposition. The presence of methane and ethane in these cases, rather than butane and pentane as seen in our case, may be related to varying temperature gradients from site to site. Although NRM intensities start to decrease at variable depths due to the differences in temperature gradients and organic matter from place to place, all these lines of evidence strongly suggest that organic decomposition in deep marine sediments can greatly diminish NRM intensity.

It is interesting to note that in the present study, there is a moderately high intensity zone (925 to $1080 \mathrm{mbsf}$ ) sandwiched between the two low-intensity zones (Figure 1). As discussed above, the sediments at 675 mbsf, where NRM intensities first decrease, were observed to have reached the minimum temperature necessary for catagenesis. Therefore, all the sediments below 675 mbsf should have experienced the temperatures necessary for organic decomposition. However, if the low-intensity zones were produced by the organic decomposition of catagenesis, as discussed previously, then this high-intensity zone should not exist.

A possible explanation may lie with the coincidental presence of the previously mentioned décollement in this intermediate NRM intensity zone (Figure 2). The décollement is an important structural feature and acts as a major conduit in accretionary prisms [Taira et al., 1991; Moore et al.1988; Moore, 1989]. We would like to suggest that either the chemistry or temperature of flowing water, or both, is 
responsible for the preservation of magnetite grains and the relatively high NRM. Magnetite, instead of hematite, will be preserved if the degree of oxidation is not too high. Similarly, a lowered temperature due to cold water flow through the décollement will reduce the ambient temperature and prevent catagenesis. Currently available data do not allow us to choose between the two hypotheses.

\section{Conclusions}

With increase in sediment depth, ambient higher temperatures cause organic matter to decompose into light hydrocarbon gases and $\mathrm{CO}_{2}$, which, in turn, results in magnetite dissolution and weak NRM intensities in deep sediments. This is a redox process: carbon in the organic matter is oxidized, and iron, manganese, and sulfur in sediments are reduced. Consequently, grain size and content of magnetite, and elemental iron and manganese content, decrease; conversely, amounts of hydrocarbon gases and sulfur increase. NRM intensities can be diminished by 1 to 2 orders of magnitude due to such drastic magnetite dissolution. Such a process of magnetite dissolution at great depth can degrade the magnetic signal, especially for sediments with a high sedimentation rate. In such situations, it may thus be better for geomagnetic fluctuation studies to use more slowly deposited abyssal sediments, even though they may not record as many details of magnetic field secular variations or dipole field transitions. The argument for avoiding such very deep sediments is even stronger if our goal is relative paleointensity, for which magnetic carriers must be uniform with depth. Based on this study, we also found that at and around the décollement in site 808 , catagenesis has been prevented, so that organic decomposition and magnetic dissolution did not take place. Therefore, the sediments have maintained high NRM intensities in the sandwiched zone around the décollement.

Acknowledgments. The authors thank R. Knurr (Geochemistry Laboratory) for help with the chemical elemental analysis, and $A$. Wang (Limnological Research Center) for sulfur content determination. The manuscript has much improved from the comments of M. Jackson, C. Hunt, B. Clement, J. King, and an anonymous reviewer. This work is supported by National Science Foundation grant EAR-9005776 and Texas A\&M Research Foundation grant P020475 to S.K. Banerjee and R. Lu. This paper is contribution 9207 from the Institute for Rock Magnetism established by the Keck Foundation, the National Science Foundation, and the University of Minnesota.

\section{References}

Bray, C. J., and D. E. Karig, Porosity of sediments in accretionary prisms and some implications for dewatering processes, J. Geophys. Res., 90 768-778, 1985.

Canfield, D. E., and R. A. Berner, Dissolution and pyritization of magnetite in anoxic marine sediments, Geochim. Cosmochim. Acta, 51, 645-659, 1987.

Cloos, M., Landward-dipping reflectors in accretionary wedges: Active dewatering conduits?, Geology, 12, 519-522, 1984.

Dankers, P. H., Magnetic properties of dispersed natural iron-oxides of known grain-sizes, Ph.D. thesis, 142 Pp., Univ. of Utrecht, Utrecht, Netherlands, 1978.

Dunlop, D. J., Hysteresis properties of magnetite and their dependence on particle size: A test of pseudo-single-domain remanence models, J. Geophys. Res., 91, 9569-9584, 1986.
Goldhaber, M. B., and 1. R. Kaplan, The sulphur cycle, in The Sea, vol. 5, Marine Chemistry, edited by E. D. Goldberg, John Wiley, New York, 1974.

Hartstra, R. L., A comparative study of the ARM and $\mathrm{I}_{\mathrm{Sr}}$ of some natural magnetites of $\mathrm{MD}$ and $\mathrm{PSD}$ grain size, Geophys. J. R. Astron. Soc., 71, 497-518, 1982.

Hunt, J. M., Petraleum Geochemistry and Geology, W. H. Freeman, New York, 1979.

Jackson, M., W. Gruber, J. Marvin, and S. K. Banerjee, Partial anhysteretic remanence and its anisotropy: Application and grainsize-dependence, Geophys. Res. Lett., 15, 440-443, 1988.

Kaplan, I. R., K. O. Emery, and S. C. Rittenbery, The distribution and isotope abundance of sulphur in recent marine sediments off southem California, Geochim. Cosmochim. Acra, 27, 297-331,1963.

Karlin, R., Magnetic mineral diagenesis in suboxic sediments at Bettis site W-N, NE Pacific Ocean, J. Geophys. Res., 95, 4421-4436, 1990.

Kent, D. V., and N. D. Opdyke, Paleomagnetic field intensity variation recorded in a Brunhes epoch deep-sea sediment core, Nature, 266 , 156-159, 1977.

King, J. W., and J. E. T. Channell, Sedimentary magnetism, environmental magnetism, and magnetostratigraphy, U.S. Nat. Rep. Union Geod. Geophys. 1987-1990, Rev. Geophys., 29, 358-370, 1991.

King, J. W., S. K. Banerjee, J. Marvin, and Ö. Özdemir, A comparison of different magnetic methods for determining the relative grain size of magnetite in natural materials: Some results from lake sediments, Earth Planet. Sci. Lett., 59, 404-419, 1982.

Kodama, K. P., and W.-W. Sun, SEM and magnetic fabric study of a compacting sediment, Geophys. Res. Lett., 17, 795-798, 1990.

Leslie, B. W., D. E. Hammond, W. M. Berelson, and S. Lund, Diagenesis in anoxic sediments from the California Continental Borderland and its influence on iron, sulfur, and magnetite behavior, J. Geophys. Res., 95, 4453-4470, 1990a.

Leslie, B. W., S. Lund, and D. E. Hammond, Rock magnetic evidence for the dissolution and authigenic growth of magnetic minerals within anoxic marine sediments of the Califormia Continental Borderland, $J$. Geophys. Res., 95, 4437-4452, $1990 \mathrm{~b}$.

Lu, R., S. K. Banerjee, and J. Marvin, Effects of clay mineralogy and the electrical conductivity of water on acquisition of depositional remanent magnetization in sediments, J. Geophys. Res. 95, 45314538, 1990.

Lu, R., S. K. Banerjee, M. Jackson, and J. Marvin, Rock magnetic study of sediments from site 808, leg 131, Proc. Ocean Drilling Program Sci. Results, 131, 293-300, 1993.

Maher, B. A., Magnetic properties of some synthetic sub-micron magnetites, Geophys. J., 94, 83-96, 1988.

Mascle, A., et al., Proceedings of the Ocean Drilling Program,. Initial Reports., vol. 110, Ocean Drilling Program, College Station, Tex., 1986.

McElhinny, M. W., and R. T. Merrill, Geomagnetic secular variation over the past 5 million years, Rev. Geophys., 13, 687-7078 1975.

Moore, J. C., Tectonics and hydrogeology of accretionary prisms: Role of the décollement zone, J. Struct. Geol. 11, 95-106, 1989.

Moore, J. C., and Scientific party of leg 110, Tectonics and hydrogeology of the northem Barbados Ridge: Results from Ocean Drilling Program leg 110, Geol. Soc. Am. Bull., 100, 1578-1593, 1988.

Özdemir, Ö., and S. K. Banerjee, A preliminary magnetic study of soil samples from west-central Minnesota, Earth Planet. Sci. Lett., 59 , 393-403, 1982.

Peacock, S. M., Thermal effects of metamorphic fluids in subduction zones, Geology, 15, 1057-1060, 1987.

Rangin, C., et al, Proceedings of the Ocean_Drilling Program,Initial Reports., vol. 124, Ocean Drilling Program., College Station, Tex., 1989.

Shipboard Scientific Party, Site 808. In Taira, A., et al., Proeedings of the Ocean Drilling Program, Initial Reports, vol. 131, Ocean Drilling Program, College Station, Tex., 71-269, 1991.

Taira, A., et al., Praceedings of the Ocean Drilling Program, Initial 
Reports., vol. 131, Ocean Drilling Program, College Station, Tex., 1991.

Tric, M., J-P Valet, P. Tucholka, M. Pateme, L. Labeyrie, F. Guichard, L. Tauxe, and M. Fontugne, Paleointensity of the geomagnetic field during the last 80,000 years, J. Geophys. Res., 97, 9337-9351, 1992.

Verosub, K., Depositional and post-depositional processes in the magnetization of sediments, Rev. Geophys., 15, 129-143, 1977.
S.K. Banerjee and R. Lu, Institute for Rock Magnetism and Department of Geology and Geophysics, 108 Pillsbury Hall, 310

Pillsbury Drive SE, University of Minnesota, Minneapolis, MN 55455.

(Received October 26, 1992; revised August 31, 1993; accepted November 11, 1993.) 